\title{
Evaluation of Water Quality Index of Pallecheruvu Surroundings
}

\author{
${ }^{1}$ S.Ramanarayan, ${ }^{2}$ A.Manjunath, ${ }^{3}$ C.Jenifa Latha, ${ }^{4}$ K.V.R. Satya Sai, ${ }^{5}$ A.S.Kanagalakshmi \\ ${ }^{1,3}$ Associate Professor,Department of Civil Engineering, Aurora's Scientific Technological Research Academy, Hyderabad, India \\ ${ }^{2}$ Assistant Professor, Department of Civil Engineering, MVSR Engineering College, Nadergul, Hyderabad, India \\ ${ }^{4}$ Research Scholar, Department of Civil Engineering, Jawaharlal Nehru Technological University, Anantapuramu, India \\ ${ }^{5}$ Professor,Department of Civil Engineering, Panimalar College of Engineering,Poonamalle, Chennai,Tamil Nadu,India \\ ramanarayan.s@gmail.com,manjunath.aluru@gmail.com,jenifalatha@gmail.com,kvr.satya.sai@gmail.com,askv26@gmail.com
}

\begin{abstract}
Water Quality Index is a concept for classification of water for different purposes and to find suitability for human consumption and industry. An effort has been made to know the ground water quality by usage of water quality index in and around Pallecheruvu lake of Bandlaguda area of South Hyderabad. 15 groundwater samples were collected from bore wells along with 4 surface water samples from the surrounding regions of Pallecheruvu Lake during the preMonsoon in the year 2017. This was done by collecting the 15 groundwater samples and subjecting them to a detailed physico-chemical analysis by using standard methods of analysis. From the data obtained aforesaid, the water quality index was calculated by following the method developed by Tiwari and Mishra. Water quality index rating was carried out to quantify overall ground water quality status of the area. For calculating the index, the following 8 characteristics have been considered like pH, Chlorides (mg/l), Acidity, Alkalinity, Total dissolved Solids, Electrical Conductivity, Turbidity. The range of WQI values is from 7.18 to 11.70 . The average value of water quality index of the samples was found in the value of 8.05 in pre-monsoon season. Post monsoon concentrations are diluted after monsoon effect. The results of the present study are very encouraging and reflect the healthy status of the lake. After analysis of WQI, all the samples indicate that water of all locations is acceptable for direct consumption and is within the permissible limit. Also,on carefully examining the data, it was concluded that most of the water quality parameters were below the desired limit as prescribed by BIS, making the water safe for consumption by man.
\end{abstract}

keywords- Ground Water, Water Quality Index,PhysicoChemical Analysis, Tiwari And Mishra,Hyderabad

\section{I.INTRODUCTION}

The main source of drinking water is ground water. It can be said that one third of the world's population uses groundwater for purpose of drinking and today more than 50 percent of the population of the world is dependent upon groundwater for living. For all water development projects, water quality is a very significant parameter as it controls all aspects of water use-by humans, by animals, by crops, and even by industry. To determine the welfare of the society, water quality is a major factor. A regular and periodic monitoring of water bodies with required number of characterstics as well as the quality of water not only prevents outbreak of disease and occurrence of other illhealth problems but also checks the water from further contamination and there by protects it. Water Quality Index (WQI) is one of the most suitable rating which reflect a combined influence of contributing factors on the quality of water for any water supply system. That's why the present work deals with WQI of drinking water collected from different locations of Bandlaguda area, Telangana, India. This Index is devised by Horton and modified by Tiwari and Mishra (1985).

\section{STUDY AREA AND PROBLEM STATEMENT}

Pallecheruvu is located in the southern part of the Hyderabad city, covering an area of about 16.8 hectares. The present study is undertaken to evaluate the quality of surface water and ground water of Pallecheruvu Lake. The assessment of groundwater quality is made through calculating the water quality parameters such as $\mathrm{pH}$, turbidity, chlorides, Hardness etc.

\section{MATERIALS AND METHODS}

Totally, 19 water samples were collected and each sample was designated as S1 to S19. The sample locations are taken by using handheld GPS receiver (table 1). Among 19 samples, the 15 water samples were taken from bore wells and 4 samples from surface water of lake. These samples were analysed for different parameters such as $\mathrm{pH}$, Chlorides (mg/l), Acidity, Alkalinity, Total dissolved Solids, Electrical Conductivity, Turbidity by following standard methods (APHA, 1998). Therefore the purpose is to study the Physico-chemical characteristics in order to understand the water quality. The samples were collected downstream of the lake. 


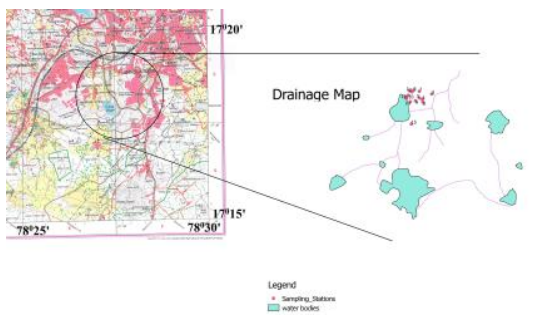

Fig.1. Location map

TABLE I. GPS Values of sample locations

\begin{tabular}{|l|l|l|l|l|}
\hline Sample & Type & \multicolumn{1}{|c|}{ Lat } & \multicolumn{1}{|c|}{ long } & Station \\
\hline S1 & Bore well & $17^{0} 18.966^{\prime}$ & $78^{0} 27.372^{\prime}$ & Ambedkar statue \\
\hline S2 & Bore well & $17^{0} 18.952^{\prime}$ & $78^{0} 27.402^{\prime}$ & pride OS function hall \\
\hline S3 & Bore well & $17^{0} 18.929^{\prime}$ & $78^{0} 27.621^{\prime}$ & White palace \\
\hline S4 & Bore well & $17^{0} 18.868^{\prime}$ & $78^{0} 27.518^{\prime}$ & Evergreen function hall \\
\hline S5 & Bore well & $17^{0} 18.885^{\prime}$ & $78^{0} 27.485^{\prime}$ & Modern Motors \\
\hline S6 & Bore well & $17^{0} 18.968^{\prime}$ & $78^{0} 27.422^{\prime}$ & Kailash Dal industry \\
\hline S7 & Bore well & $17^{0} 18.958^{\prime}$ & $78^{0} 27.485^{\prime}$ & GMR parking \\
\hline S8 & Bore well & $17^{0} 18.840^{\prime}$ & $78^{0} 27.523^{\prime}$ & Amar Boys Hostel \\
\hline S9 & Bore well & $17^{0} 18.854^{\prime}$ & $78^{0} 27.442^{\prime}$ & Rose garden \\
\hline S10 & Bore well & $17^{0} 18.915^{\prime}$ & $78^{0} 27.366^{\prime}$ & ZAS motors \\
\hline S11 & Bore well & $17^{0} 18.897^{\prime}$ & $78^{0} 27.345^{\prime}$ & Resident building-1 \\
\hline S12 & Bore well & $17^{0} 18.881^{\prime}$ & $78^{0} 27.342^{\prime}$ & Resident Building-2 \\
\hline S13 & Bore well & $17^{0} 18.895^{\prime}$ & $78^{0} 27.334^{\prime}$ & Resident building-3 \\
\hline S14 & Bore well & $17^{0} 18.844^{\prime}$ & $78^{0} 27.386^{\prime}$ & Pallecheruvu Temple \\
\hline S15 & Bore well & $17^{0} 18.600^{\prime}$ & $78^{0} 27.397^{\prime}$ & Aurora College \\
\hline S16 & Surface water & $17^{0} 18.788^{\prime}$ & $78^{0} 27.387^{\prime}$ & Pallecheruvu centre \\
\hline S17 & Surface water & $17^{0} 18.703^{\prime}$ & $78^{0} 27.409^{\prime}$ & Pallecheurvu corner \\
\hline S18 & Surface water & $17^{0} 18.844^{\prime}$ & $78^{0} 27.386^{\prime}$ & Pallecheurvu corner \\
\hline S19 & Surface water & $17^{0} 18.307^{\prime}$ & $78^{0} 27.200^{\prime}$ & Pallechuruvu corner \\
\hline
\end{tabular}

\section{WATER QUALITY INDEX ESTIMATION}

Water Quality Index (WQI) is defined as a value that reflects the combined influence of different water quality characteristics on the overall quality of water. Horton (1965) was among the first to give an idea of the concept of indices to represent water quality. The WQI has been calculated to evaluate the groundwater quality of the study area for purpose of drinking. The BIS code for drinking purposes is considered for the calculation of WQI.To calculate WQI, six parameters such as: $\mathrm{pH}$, TDS, turbidity, acidity, alkalinity, chlorides have been used.To calculate WQI the following four steps are to be adhered.

A. Step-I

- Every 1 parameter out of the 6 parameters is allotted a weight (wi) according to their relative significance in the overall water quality for purpose of drinking.

- A maximum weight 5 was allotted to parameters such as chlorides due to their major importance in water quality assessment (srinivasamoorthy et al., 2008).

- Rest of the parameters were allotted a value of weight in between 1 to 5 that depends on their importance in the overall water quality for purpose of drinking.

\section{B. Step-II}

The relative weight $(\mathrm{w})$ is calculated by using a weighted arithmetic index method given underneath (Brown et al., 1972; Horton, 1965; Tiwari and manzoor, 1988) in the steps that follow.

$$
W_{i}=\frac{W_{i}}{\sum_{i=1}^{n} W_{i}}
$$

Where, $\mathrm{W}_{\mathrm{i}}$ is the relative weight and $\mathrm{w}$ is the weight of each parameter and $\mathrm{n}$ is the number of parameter.

TABLE II. WHO Standards, Weight, relative weight of each parameter

\begin{tabular}{|c|c|c|c|}
\hline Parameters & Indian Standard & Weight $\left(\mathrm{w}_{\mathrm{i}}\right)$ & Relative Weight \\
\hline $\mathrm{pH}$ & $6.5-8.5$ & 4 & 0.1739 \\
\hline Total dissolved solids & $500 \mathrm{mg} / \mathrm{lit}$ & 4 & 0.1739 \\
\hline Turbidity & $1 \mathrm{NTU}$ & 3 & 0.1304 \\
\hline Chlorides & $250 \mathrm{mg} / \mathrm{lit}$ & 3 & 0.1304 \\
\hline Conductivity & $3000 \mu \mathrm{mhos} / \mathrm{cm}$ & 3 & 0.1304 \\
\hline Alkalinity & $200 \mathrm{mg} / \mathrm{lit}$ & 3 & 0.1304 \\
\hline Acidity & $200 \mathrm{mg} / \mathrm{lit}$ & 3 & 0.1304 \\
\hline
\end{tabular}

\section{Step-III}

A quality rating scale (Qi) for each parameter is allotted by division of its concentration in each sample of water by its respective standard according to the guidelines of BIS code and then afterwards multiplied by 100 .

$$
Q_{i}=\frac{C_{i}}{S_{i}} * 100
$$

where $\mathrm{Q}_{\mathrm{i}}$ is the quality rating, $\mathrm{C}_{\mathrm{i}}$ is the concentration of each chemical characteristic in each water sample in $\mathrm{mg} / \mathrm{l}$ and $\mathrm{S}_{\mathrm{i}}$ is the drinking water standard for each chemical characteristic in $\mathrm{mg} / \mathrm{lit}$ according to the guidelines of BIS code.

\section{D.Step-IV}

The SIi is first found for each parameter, which is then used to compute the WQI as shown in equation below:

$$
S I_{i}=W_{i} * Q_{i}
$$

Where $\mathrm{SI}_{\mathrm{i}}$ is the sub index of ith parameter and $\mathrm{Q}_{\mathrm{i}}$ is the rating based on concentration of $i^{\text {th }}$ parameter. The overall water quality index (WQI) was computed by summing up together each of the sub index values of each samples of groundwater as below:

$$
W Q_{i}=\sum S I_{i}
$$


TABLE III. Results of Water Quality Index

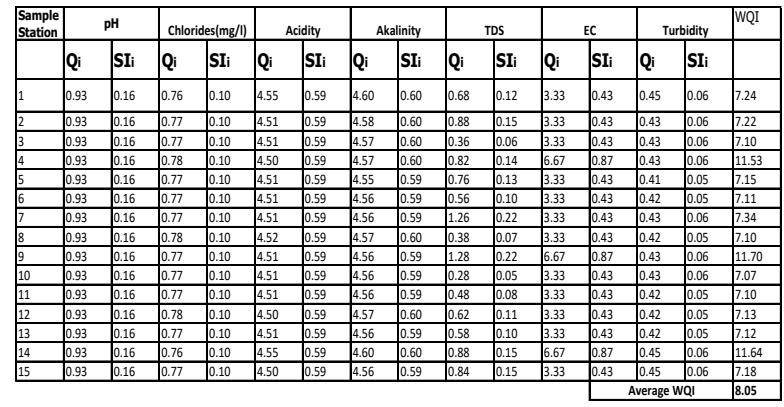

\section{RESULTS AND DISCUSSIONS}

The variation in physico-chemical characteristics of the surface water, and bore well water of the lake have been summarized in the tables 4. Monitoring lakes requires many different parameters to be sampled. The parameters analyzed

in this assessment include:

A. $p H$ : The $\mathrm{pH}$ of a solution is the negative logarithm of Hydronium ion concentration in moles/litre. According to Bureau of Indian Standard(BIS),the permissible limit of $\mathrm{pH}$ in drinking water is within $6.5-8.5$ The value of $\mathrm{pH}$ in all samples of water is within the permissible range. The value of $\mathrm{pH}$ in groundwater samples of the study area ranges from $6.98-7.83$.

B. Total dissolved solids: Solids is the material suspended or dissolved in water or wastewater. Solids affects water quality severely in a number of ways. Waters with high number of dissolved solids generally are at poor waters. The value of TDS of the study area ranges from 140 $700 \mathrm{mg} / \mathrm{l}$ in ground water samples. $21 \%$ of samples were above the standard limit of $500 \mathrm{mg} / \mathrm{l}$ as prescribed by BIS.

C. Electrical Conductivity: The values of EC ranged from 0.1 and 0.2 (siemens $/ \mathrm{cm})$.

$D$. Chloride: The Chloride concentration in the study area ranges from $152-162 \mathrm{mg} / 1.250 \mathrm{mg} / \mathrm{l}$ is the permissible limit of chloride. $100 \%$ of samples were within the standard limit prescribed by BIS.

E. Total Alkalinity: The values of alkalinity at stations range from $910-927 \mathrm{mg} / 1.100 \%$ samples were found above the standard limit of $200 \mathrm{mg} / \mathrm{l}$ as prescribed by BIS. Water with high alkalinity is said to be "hard." Calcium carbonate causes alkalinity. $\mathrm{CaCO}_{3}$ comes from rocks such as limestone or can be leached from dolomite and calcite in the soil. Water gets bitter taste with increase in alkalinity.

F. Turbidity: The turbidity for all the water samples is below the BIS Standard limit of 1.0 NTU. Out of 19 samples, the highest value of turbidity obtained is 0.45 NTU. Turbidity in water causes loss in clarity.

$G$. The profile of water quality parameters is presented below.

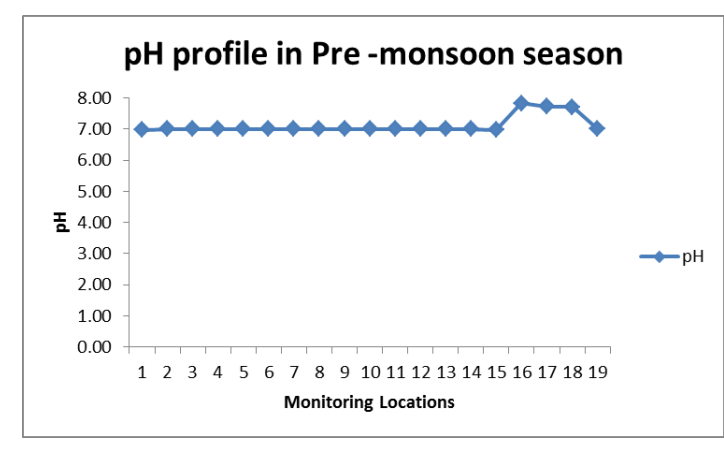

Fig.2.pH profile

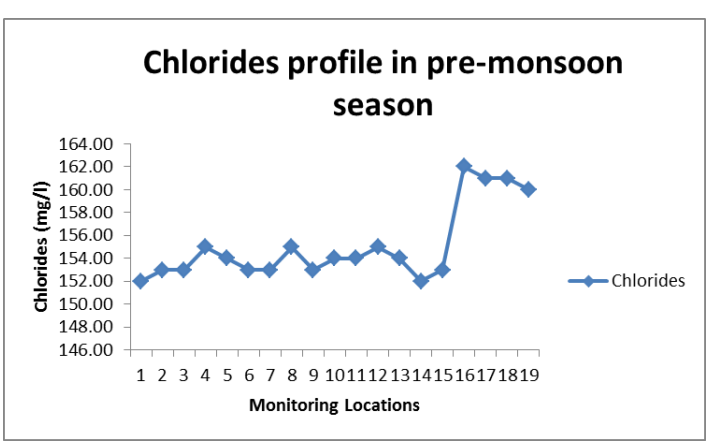

Fig.3.Chlorides profile

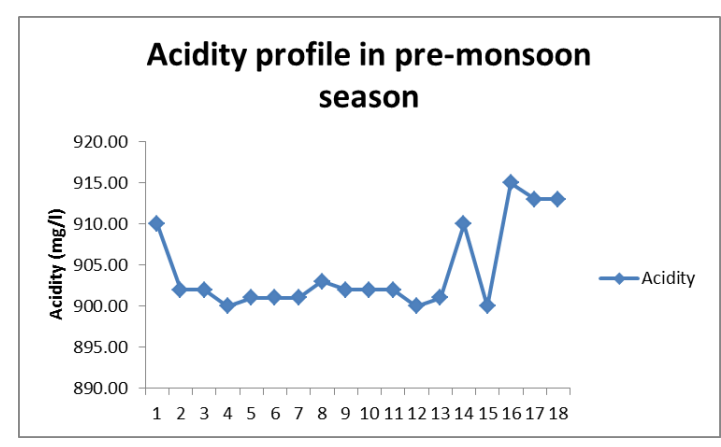

Fig.4. Chlorides profile

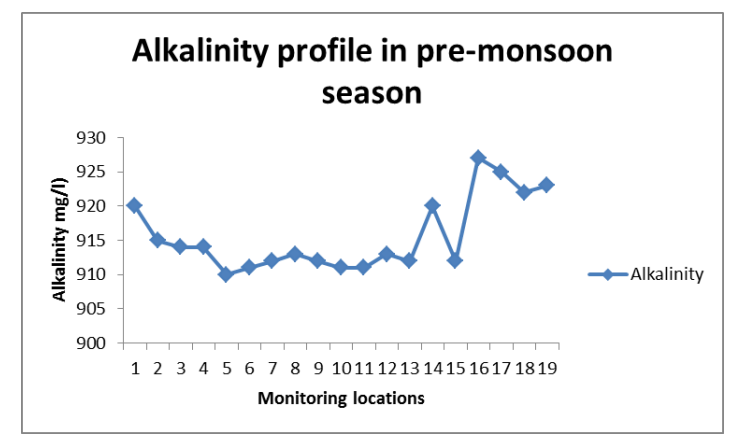

Fig.5.Alkalinity Profile 


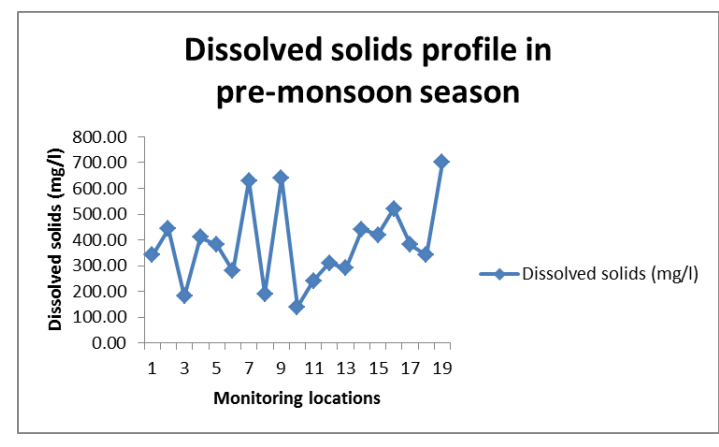

Fig.6.Dissolved solids profile

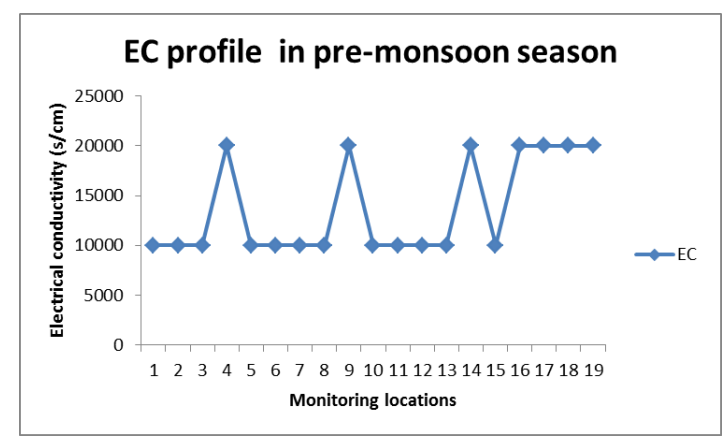

Fig.7. Electrical conductivity profile

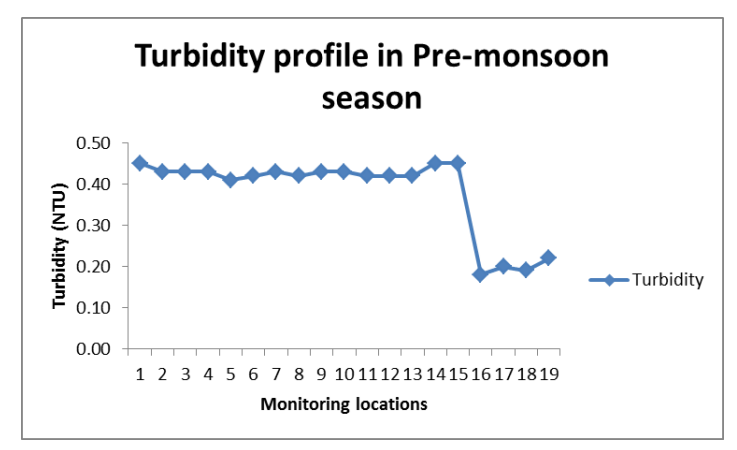

Fig.8.Turbidity profile
TABLE IV. water quality parameters at different stations

\begin{tabular}{|l|r|r|r|r|r|r|r|}
\hline Sample ID & \multicolumn{1}{|c|}{$\mathbf{p H}$} & $\begin{array}{c}\text { Chlorides } \\
\text { (mg/l) }\end{array}$ & $\begin{array}{c}\text { Acidity } \\
\text { (mg/l) }\end{array}$ & $\begin{array}{c}\text { Alkalinity } \\
\text { (mg/l) }\end{array}$ & \multicolumn{1}{c|}{ DS(mg/l) } & EC(s/cm) & $\begin{array}{c}\text { Turbidity(N) } \\
\text { TU) }\end{array}$ \\
\hline S1 & 6.98 & 152.00 & 910.00 & 920.00 & 340.45 & 10000.00 & 0.45 \\
\hline S2 & 7.00 & 153.00 & 902.00 & 915.00 & 442.35 & 10000.00 & 0.43 \\
\hline S3 & 7.00 & 153.00 & 902.00 & 914.00 & 180.37 & 10000.00 & 0.43 \\
\hline S4 & 7.00 & 155.00 & 900.00 & 914.00 & 410.32 & 20000.00 & 0.43 \\
\hline S5 & 7.00 & 154.00 & 901.00 & 910.00 & 380.53 & 10000.00 & 0.41 \\
\hline S6 & 7.00 & 153.00 & 901.00 & 911.00 & 280.15 & 10000.00 & 0.42 \\
\hline S7 & 7.00 & 153.00 & 901.00 & 912.00 & 630.32 & 10000.00 & 0.43 \\
\hline S8 & 7.00 & 155.00 & 903.00 & 913.00 & 190.73 & 10000.00 & 0.42 \\
\hline S9 & 7.00 & 153.00 & 902.00 & 912.00 & 640.73 & 20000.00 & 0.43 \\
\hline S10 & 7.00 & 154.00 & 902.00 & 911.00 & 140.32 & 10000.00 & 0.43 \\
\hline S11 & 7.00 & 154.00 & 902.00 & 911.00 & 240.35 & 10000.00 & 0.42 \\
\hline S12 & 7.00 & 155.00 & 900.00 & 913.00 & 310.63 & 10000.00 & 0.42 \\
\hline S13 & 7.00 & 154.00 & 901.00 & 912.00 & 290.35 & 10000.00 & 0.42 \\
\hline S14 & 7.00 & 152.00 & 910.00 & 920.00 & 440.56 & 20000.00 & 0.45 \\
\hline S15 & 6.98 & 153.00 & 900.00 & 912.00 & 418.32 & 10000.00 & 0.45 \\
\hline S16 & 7.83 & 162.00 & 915.00 & 927.00 & 520.35 & 20000.00 & 0.18 \\
\hline S17 & 7.73 & 161.00 & 913.00 & 925.00 & 380.43 & 20000.00 & 0.20 \\
\hline S18 & 7.71 & 161.00 & 913.00 & 922.00 & 340.89 & 20000.00 & 0.19 \\
\hline S19 & 7.00 & 160.00 & 910.00 & 923.00 & 700.76 & 20000.00 & 0.22 \\
\hline Min. & 6.98 & 152.00 & 900.00 & 910.00 & 140.32 & 10000.00 & 0.18 \\
\hline Max. & 7.83 & 162.00 & 915.00 & 927.00 & 700.76 & 20000.00 & 0.45 \\
\hline Average & 7.12 & 155.11 & 904.63 & 915.63 & 383.10 & 13684.21 & 0.38 \\
\hline
\end{tabular}

\section{CONCLUSION}

The quality of groundwater taken from the study area was studied by analysing the Physico-chemical characteristics. The main idea of this study was to create a digital database, and to map and determine the groundwater quality in study area. From the study, the inference that can be made is that the $\mathrm{pH}$ in most of the wells in the region is acidic and alkaline in nature. The $\mathrm{WQI}<50$ for all ground water samples. Water is excellent for drinking purpose.

\section{REFERENCES}

[1] P. J. Puri, M. K. N. Yenkie, S. P. Sangal, N. V. Gandhare, G. B. Sarote and D. B. Dhanorkar - "Surface water (Lakes) quality assessment in Nagpur city (India) based on Water quality index (WQI)", Vol.4, No.1, 43-48 (2011).

[2] B. N. Tandel, Dr. J. Macwan and C. K. Soni - "Assessment of Water Quality Index of Small Lake in South Gujarat Region, India."

[3] S. Chandra, A. Singh and P. K. Tomar - "Assessment of Water Quality Values inPorur Lake chennai, Hussain Sagar Hyderabad and Vihar Lake Mumbai,India", Chem Sci Trans., 1(3), 508-515,2012.

[4] Wu-Seng Lung, A. M. Asce - "Lake Acidification Model: Practical tool", J.Environ. Eng.113:900-915, 1987.

[5] T. M. Heidtke, A. M. Asce and W. C.Sonzogni - "Water Quality Management for the Great Lakes", J. Water Resour. Plann. Manage. 112:48-63, 1986.

[6] V. Pradhan, M. Mohsin, B. H. Gaikwad -"Assessment of physico chemical parameters of Chilika Lake water", International Journal of Research in Environmental Science and Technology, 2(4): 101-103, 2012.

[7] Dr. M. K. Mahesh, B. R. Sushmitha, H. R. Uma - "Assessment of Water Quality for Hebbal Lake of Mysore", ISSN No. 2277- 8160, Volume: 2, Issue: 2, Feb 2013.

[8] M. S. Islam, B. S. Ismail, G. M. Barzani, A. R. Sahibin and T. M. Ekhwan - "Hydrological Assessment and Water Quality Characteristics of Chini Lake, Pahang, Malaysia", AmericanEurasian J.Agric. \& Environ. Sci., 12 (6): 737-749, 2012.

[9] V. B. Y. Sheikh, P. R. Bhosale, B. N. Nagargoje - "Water Quality Assessment ofNagzari Dam of Maharashtra." Journal of Applied 
Technology in Environmental Sanitation, Volume 3, Number 3: 111 116, October 2013.

[10] S. Hussaina, V. Maneb, S. Takdea, A. Pathanc, M. Farooquic - " Comparison between Treated and Untreated water so as to study water treatment plant of Ahmadpur Dist. Latur," International Journal of Modern Engineering Research (IJMER) www.ijmer.com, Vol.1, Issue2, pp- 564-569, ISSN: 2249-6645.

[11] R. W. Gaikwad, V. V. Sasane - "Assessment of ground water quality in and around Lonar lake and possible water treatment", International Journal of Environmental Sciences, Volume 3, No 4, 2013.

[12] S. N. Thitame and G. M. Pondhe, -"Assessment of seasonal variation in physico-chemical characteristics and quality of Pravara River water for irrigation use in Sangamner, Dist.Ahmednagar, Maharashtra", Journal of Chemical and Pharmaceutical Research, J. Chem. Pharm. Res., 2(2): 316-320, 2010.

[13] M. Pejaver, M. Gurav - "Study of Water Quality of Jail and Kalwa Lake, Thane, Maharashtra", J. Aqua. Biol. Vol. 23(2), 44 -50, 2008.

[14] R. M. Khan, M. J. Jadhav, I. R. Ustad - "Physicochemical Analysis of Triveni Lake Water of Amravati District in (M.S.) India. Bioscience Discovery, 3(1):64-66, Jan.2012.

[15] S. P. Gorde, M. V. Jadhav,Assessment of Water Quality Parameters: A Review,Int. Journal of Engineering Research and Applications,ISSN : 2248-9622, Vol. 3, Issue 6, Nov-Dec 2013, pp.2029-2035.

[16] S. Priya, S. Sam Manohar Das and K. Vareethiah,Analysis of Water Quality in Selected Stations along River,Tambaraparani Kanyakumari District, Tamilnadu, India,International Journal of Innovative Science, Engineering \& Technology, Vol. 3 Issue 8, August 2016

[17] Anima Upadhyay, M. Chandrakala ,A Study on the Water Quality Parameters of Kukkarahalli Lake Water Mysore, Karnataka, India,Volume IV, Issue XII,December 2015,IJLTEMAS,ISSN 2278 $-2540$

[18] M.R.Mahananda, B.P.Mohanty\& N.R. Behera, Physico-chemical analysis of surface and groundwater of Bargarh district, Orissa, India,IJRRAS 2 (3), March 2010.

[19] Usha N M, Jayaram K C Lakshmi Kantha H,Assessment of Surface and Ground water Quality of Hebbal Lake,Bangalore-Case Study,Proceedings of Taal2007: The 12th World Lake Conference: $1737-1741$.

[20] A Comprehensive Laboratory Manual for Environmental Science and Engineering by Pillai, P.R. Sreemahadevan,New Age International Publishers,Publication Year : Apr, 2009,Edition : 1st.

[21] Elements of Environmental Engineering, 3/e,Dr. K N Duggal, S. Chand Publishing.

[22] Water Supply and Sanitary Engineering (Including Environmental Engineering \& Pollution Control Acts),Author : G.S.Birdie \& J.S.Birdie, 9th edition, reprint 2015, Dhanpat Rai Publishing.

[23] Water Quality Standards in India (IS 2296:1992). 